\title{
51. A Preliminary Note on the Functional Differentiation of the Stigma in Bombyx mori, $L$.
}

\author{
By Shigetaro Morr.
}

Imperial Sericultural Experiment Station, Tokyo.

(Rec. March 5, 1926. Comm. by Chiyomatsu Ishrk 1 wa, M.I.A., March 12, 1926.)

In the previous paper I reported that the sizes of the larval spiracles in the silkworm are different according to the segments to which they belong. Among the nine pairs of the spiracles, VIII and IX are the largest, especially the latter. $I$ is somewhat smaller than these. And the rest, i.e. II-VII, being nearly the same in size, belongs to the smallest ones, which may briefly be shown in the following tables:

\begin{tabular}{|c|c|c|c|c|c|c|c|c|c|c|c|}
\hline Segments & 1 & 2 & 3 & 4 & 5 & 6 & 7 & 8 & 9 & 10 & 11 \\
\hline Spiracles & I & & (r) & II & III & IV & $\mathrm{V}$ & $\mathrm{VI}$ & VII & VII & IX \\
\hline \multicolumn{3}{|c|}{ Spiracles } & I & II & III & IV & $\mathrm{V}$ & VI & VII & VIII & IX \\
\hline \multirow{3}{*}{$\begin{array}{l}\text { Yamato- } \\
\text { nishiki } \\
\text { (Jap. race) }\end{array}$} & \multirow{3}{*}{\multicolumn{2}{|c|}{$\begin{array}{l}\text { Length } \\
\text { Breadth } \\
\mathrm{L} \times \mathrm{B}\end{array}$}} & 1.14 & 1.00 & 1.04 & 1.06 & 1.05 & 1.04 & 1.04 & 1.27 & 1.34 \\
\hline & & & 1.11 & 1.00 & 1.01 & 1.04 & 1.02 & 1.01 & 1.00 & 1.17 & 1.23 \\
\hline & & & 1.25 & 1.00 & 1.05 & 1.10 & 1.07 & 1.05 & 1.04 & 1.48 & 1.64 \\
\hline \multirow{3}{*}{$\begin{array}{l}\text { Szeksz'ard } \\
\text { (Europ. race) }\end{array}$} & \multirow{2}{*}{\multicolumn{2}{|c|}{$\begin{array}{l}\text { Length } \\
\text { Breadth }\end{array}$}} & 1.14 & 1.00 & 1.05 & 1.07 & 1.08 & 1.08 & 1.08 & 1.26 & 1.31 \\
\hline & & & 1.06 & 1.02 & 1.02 & 1.03 & 1.01 & 1.03 & 1.00 & 1.14 & 1.18 \\
\hline & \multicolumn{2}{|c|}{$\mathrm{L} \times \mathrm{B}$} & 1.19 & 1.00 & 1.05 & 1.09 & 1.07 & 1.09 & 1.06 & 1.42 & 1.53 \\
\hline
\end{tabular}

The above table shows the comparative size of the spiracles calculated from the actual observation, the smallest one being taken as the unit.

(r) denotes the rudimentary spiracle.

Experiments which prove that the spiracles are indispensable to the insects as orifices for the respiration by shutting them artificially were carried out by Malpighi (1669), 'Treviranus (1832), Landois (1867), SASAKI (1907), BABÁK (1902) and LEE (1925). The above authors, however, with the exception of LEE, made no observations as to whether any functional differences are to be seen among them, while they all 
agree in having observed the abnormal behaviors of the animals as well as the muscular paralysis that follows directly from shutting the spiracles by means of oil, butter, bee's wax, vaserine dc. LeE, using several species of the grasshoppers (imagoes), found that out of ten pairs of spiracles, two thoracic and the first two abdominal ones are inspiratory in function, whereas the last six pairs of abdominal spiracles are expiratory. As the silkworm larva which indicates no special respiratory movements, the manners of respiration as well as the function of the spiracles are expected to be quite different from those observed in the imagoes of other insects, the facts which have induced me to carry out a series of experiments. The purpose of the present experiments was to determine whether there is a certain relation between the sizes of the stigmas and their respiratory functions. For these purposes I used the larvae of two bivoltine races: Jap. No. 107. and Chin. No. 101. as materials and cemented the whole or a part of spiracles with black enamel paint or with black asphalt varnish in every possible manners and in several stages of the development of the animals and thus by shutting the spiracles have arrived to a conclusion which, so far as my knowledge is concerned, appears to be new to science. The experiments were carried out during the year 1925 from spring till late in autumn, the result of which may be summarized in the following categories ;

(1). The harn the animals suffer from the shutting up of the spiracles, being highly complicated, differs greatly according to the temperature to which they are exposed, numbers of spiracles shut, their position, the age of the animals and the individuals. In general, high room temperature and the aged animals, even within the same age those that are full grown or those just before the moulting show a marked hindrance than those exposed to the lower temperature and those that are younger. Throughout the experiments two sorts of hindrances may be observed: the one that makes its appearance in causing the agony of the whole body and in producing the muscular paralysis, the other in the hindrance in the circulation of blood or pulsation.

(2). The shutting up of the proximal pair; of spiracles gives rise directly to, when the spiracles shut are few in number, the hanging down of the head, the state of quiescence of the animals, an impaired appetite, as the result of which the bad growth, and an appearance of a slight depression at the basal portion attaching to the integument of some of the distal pairs of the alary muscles on pulsation. If, however, the spiracles shut are more in number, the animals vomit the digestive fluid at once or bend the bodies by twisting, the abdominal legs being 
suspended above the bed on which they lay themselves, and at last they lay down the bodies side-ways, showing no response to the mechanical excitation. Muscles become loose showing distinctly the symptoms of agony and paralysis. The above symptoms appear directly after shutting the spiracles and are very acute. My experiments show that the successive shutting of the spiracles I-IV gives rise to a marked symptoms, especially the shutting of I and II, which proves that these are closely related to the above phenomena.

(3). On the contrary, when some of the distal pairs of spiracles are shut, the animals show no sign of agony, If the spiracles shut are few in number the animals take meals as usual, not showing any marked difference from the normal carterpillers in their behaviors. But the modification in plusation soon sets in. When the spiracles shut are more in number, the pulsations of the animals become greatly decreased, the discharge of excrements ceases, showing the symptoms of the costiveness and the excrements located in the caecum become small and irregular in form, sometimes two or more soft ones are found connected together. At last the pulsation stops and the animal dies. The above symptoms occur very slowly, quite contrary to those of the previous category. The shutting up of the two pairs of spiracles VIII and IX show's a sign of the modification and the decrease of pulsation. The successive shutting up of the distal three or four pairs of spiracles in the fifth age (full grown stage) the plusation decreases greatly at $75-80^{\circ} \mathrm{F}$. and the animals die at the end of $20-40$ hours.

The above experiments show that the ventilations through the distal spiracles, especially VIII and IX are intimately related to the circulation of the blood of the experimented animals.

(4). The spiracles located in the middle of the body segments i.e. III-VI show no marked hindrance as described above or only a comparatively slight hindrance can be detected, even though these are shut up successively.

(5). We thus see that there is a functional differentitation in the larval spiracles, so far as my shutting experiments are concerned. Inasmuch as they are, however, connected with ench other by means of the main tracheal trunks and the transverse branches, the hindrance caused by shutting up a certain kind of spiracles may be compensated by the adjacent ones which stand open.

Under these circumstances we are unable, so far as the present experiments are concerned, to determine the influence of shutting a single spiracle, but through a large number of experiments carried out for 
these purposes it is to be assured that the two proximal spiracles I and II, and the two distal ones VIII and IX are indispensable for the maintenance of the life of the carterpiller.

(6). It is evident that these phenomena are due to the deficiency or insufficient supply of oxygen. The special symptoms caused by the shutting up of certain kinds of spiracles, may probably be due to the harm done to various organs, of which the muscles and the nerve-centres which receive the tracheal branches of capillaries from these spiracles in question, are especially injured.

\section{Literatures cited.}

BıвÁк, E. 1912. Untersuchungen über die Atemzentrentätigkeit bei den Insekten. Pflüger's Archiv. Bd. 147.

1921. Die Mechanik und Innervation der Atmung. H. Winterstein, Handbuch der vergleichenden Physiologie, Bd. 1, 2. Hälfte, S. 362-534.

Landors und Thelen. 1867. Der Tracheenverschluss bei den Insekten. Zeitsch. f. Wiss. Zool. Bd. 17.

LEE, M. O. 1925. On the mechanism of respiration in certain Orthoptera. Jour. Exp. Zool. Vol. 41. No. 2.

Ma LPIEHI, M. 1669. Dissertatio epistolia de Bombyce. Societa Regiae Londoni.

MoRI, S. 1922. Contribution of the knowledge of the closfng apparatus of the stigma in Bombyx mori, L. (in Japanese) Dobutsugaku-Zasshi. Vol. 41. No. 408.

SaSAKI, C. 1912. On the pathology of Jaundice of the silk-worm. Jour. Coll. Agr. Vol. II. No. 2.

Treviranus, G.R. 1832. Die Erscheinung des organischen Lebens. Bremen. 